\title{
OBSERVATIONS ON NORTHERN PINE SNAKE (PITUOPHIS M. MELANOLEUCUS) NESTING AND BEHAVIOR IN THE NORTH CAROLINA SANDHILLS
}

\author{
JEFFREY C. BEANE ${ }^{1 *}$ and L. TODD PUSSER ${ }^{2}$ \\ ${ }^{1}$ North Carolina State Museum of Natural Sciences, Research Laboratory, MSC \#1626, Raleigh, NC 27699-1626 \\ *Corresponding author, jeff.beane@ncdenr.gov \\ ${ }^{2}$ P.O. Box 122, West End, NC 27376
}

\begin{abstract}
Nesting behavior in the Northern Pine Snake (Pituophis m. melanoleucus) is poorly documented outside of the New Jersey Pine Barrens. Two natural nests of P. m. melanoleucus are described from the North Carolina Sandhills. One was modified from a pre-existing subterranean refugium, and was also used by at least one adult male; one adult female; and one post-emergent, postecdytic hatchling Pine Snake during the same season.
\end{abstract}

Key Words: Pituophis m. melanoleucus; Northern Pine Snake; nesting; North Carolina; Sandhills.

Female Pine Snakes (Pituophis melanoleucus) have long been known to excavate their own nest chambers, at least in portions of their range (Moore 1893; Zappalorti et al. 1983). Burger and Zappalorti (1986, 1991, 1992) reported extensively on the nesting behavior of Northern Pine Snakes (P. m. melanoleucus) in the New Jersey Pine Barrens. However, data on nesting in other portions of the range of $P . m$. melanoleucus remain scant. Beane and Pusser (2007) described a single nest from the Sandhills region of North Carolina and herein two additional natural nests from that region.

A natural P. m. melanoleucus nest was located 17 September 2010, after a telemetered adult female either was killed and consumed by an unknown predator, or expelled her transmitter (see Pearson and Shine 2002). The female (non-gravid when first found) was originally captured at $0938 \mathrm{hr}$ EDT 8 August 2010, abroad in open, xeric, sandy woods dominated by Longleaf Pine (Pinus palustris), Turkey Oak (Quercus laevis), and Wiregrass (Aristida stricta) (Sandhills Game Lands, ca. $19.3 \mathrm{~km}$ WNW of Wagram, Scotland County, North Carolina). She was surgically implanted with a radio transmitter (model \#\# SI-2T, Holohil Systems Ltd., Carp, Ontario, Canada) on 20 August 2010, released at the capture site that same evening, and tracked until her transmitter was found in late evening on 17 September 2010. No remains of the snake were found other than a small piece of epidermis from a ventral scute, suggesting the snake could have been pre-ecdytic when (and if) killed. Eleven and 12 days earlier, on 5 and 6 September 2010, the snake had been located underground in a refugium at the base of several small Turkey Oak saplings that had apparently sprouted from a stump, $38 \mathrm{~m}$ from where the transmitter was found and $412 \mathrm{~m}$ from the snake's original capture site. At that time we noticed that a small quantity of sand had been excavated from the entrance of the small stump hole. We assumed that a mammal might have been responsible for the excavation, which appeared to have been done several weeks earlier. A telemetered adult male Pine Snake had been located 15 May 2010 in this same refugium. At that time, no sand had been excavated from the hole, and the entrance was relatively inconspicuous.

Upon discovering the transmitter, the immediate vicinity was searched in hope of locating more evidence of the apparent predation. Examination of the area around the snake's last known refugium revealed recently shed natal skins of eight hatchling Pine Snakes, all scattered in surface litter within an area of ca. $1 \mathrm{~m}^{2}$ and $\leq 1 \mathrm{~m}$ from the entrance of the refugium. The following morning (18 September 2010), we returned and carefully excavated the nest chamber, which contained eight adherent, recently hatched eggshells, one spoiled egg, and one live female hatchling. The nest tunnel was ca. $168 \mathrm{~cm}$ in total length. The nest chamber measured ca. $50 \times 37 \mathrm{~cm}$. The bottom of the chamber was $20 \mathrm{~cm}$ below the surface. A small hole, ca. $2 \mathrm{~cm}$ in diameter, led down into the nest chamber from directly above, suggesting the hatchlings may have exited (and/or the one re-entered) through this hole. The main entrance hole measured ca. $7 \mathrm{~cm}$ in diameter, and a second hole, several $\mathrm{cm}$ away, measured ca. $4.5 \mathrm{~cm}$ in diameter. The shed skins were found directly above the nest chamber by the small apparent emergence hole, rather than in or by the main nest entrance holes.

Of special interest are that the refugium was used by an adult male, apparently before it was enhanced for a nest chamber by a nesting female; and that it was occupied by a female at about the same time the eggs must have been hatching. We suspect that the telemetered female excavated the nest and deposited the eggs, 
but there is no conclusive evidence of this; the nest could have been from a different female. That the telemetered female may have produced the nest and then revisited it at or near hatching time suggests parental care, but her presence there could have been simply refugium fidelity or coincidence. Also of interest is the fact that one hatchling evidently emerged, molted, and then reentered the nest chamber (assuming the hatchling emerged from this nest rather than a different one). The lack of older eggshell remains or evidence of any previous digging suggest the refugium was not used as a nest in previous years. The eggshells and spoiled egg are deposited in the collection of the North Carolina State Museum of Natural Sciences (NCSM 77345). The hatchling was photographed and released back in the nest chamber. Interestingly, one year later a second telemetered adult male Pine Snake was found 10 and 11 September 2011 using the same stump hole complex as a refugium, having entered a small hole $<2 \mathrm{~m}$ from what had been the nest entrance. He was found there again on 30 March 2012.

A telemetered female $P$. m. melanoleucus was found 24 June 2011, at 1,904 hr EDT, excavating a nest (Sandhills Game Lands, ca. 18.2 km WNW of Wagram, Scotland Co., North Carolina), in relatively open Longleaf Pine-Turkey Oak-Wiregrass woods. She was found still digging at 1,025 hr 25 June 2011, with only her tail tip visible in the burrow's entrance. At $0806 \mathrm{hr}$ 26 June 2011, she was found resting on the surface, $<1 \mathrm{~m}$ from the nest burrow, and still noticeably gravid. At $1,855 \mathrm{hr}$ on 1 July and at $0846 \mathrm{hr}$ on 2 July, she was underground in the nest burrow. At $0845 \mathrm{hr} 3$ July she was found ca. $157 \mathrm{~m}$ from the nest, actively moving back toward the core of her usual home range, no longer gravid, her eggs having been deposited sometime between 26 June and 3 July 2011. Revisiting the nest several times in August, September, and October 2011, no signs of hatchling emergence were detected. We attempted to excavate the nest 16 October, but the nest chamber was not located; a large Turkey Oak stump and roots were encountered, which greatly inhibited excavation. Returning 3 December 2011 with heavier digging implements, we located the nest chamber, which contained a cluster of eight hatched, adherent eggshells. The nest chamber measured ca. $20 \times 20 \mathrm{~cm}-$ barely large enough to accommodate the female. The bottom of the chamber was ca. $26 \mathrm{~cm}$ below the surface-only slightly deeper than any of 93 New Jersey nests reported by Burger and Zappalorti (1991). The nest tunnel had partially collapsed and was difficult to follow, but was estimated to be at least $145 \mathrm{~cm}$ long. The female had apparently encountered the stump and roots while digging, and excavated around them until an open area of sand was encountered. It is not known whether the female constructed the nest burrow entirely "from scratch," or whether a pre-existing entrance hole and/or partial tunnel were present. From all appearances there was little or no pre-existing burrow, but a partial root tunnel could have been present as a result of the subterranean stump. The site appeared not to have been used as a nest previously. No trace of natal shed skins were ever found. The eggshells are deposited in the collection of the North Carolina State Museum of Natural Sciences (NCSM 78982).

These observations represent only the second and third published descriptions of $P$. m. melanoleucus nests outside of the New Jersey Pine Barrens. Tunnel lengths for both nests and chamber depth for one nest were comparable to those reported for New Jersey nests by Burger and Zappalorti (1986, 1991), whereas the one North Carolina nest reported previously was substantially deeper than any reported from New Jersey and had a shorter entrance tunnel than most (Beane and Pusser 2007). Both nests reported here were dug in areas with relatively dense, thick roots and partial stumps; New Jersey Pine Snakes typically abandon the site and nest elsewhere when such substrata are encountered (Burger and Zappalorti 1991). Robert T. Zappalorti (pers. comm.) reported only one record of a Pine Snake ovipositing in a stump hole during several decades of fieldwork with the species in New Jersey. Lee et al. (2011) reported a clutch of Black Pine Snake (P. m. lodingi) eggs from Perry County, Mississippi, found in a Gopher Tortoise (Gopherus polyphemus) burrow at a depth of $74 \mathrm{~cm}$ - apparently the deepest $P$. melanoleucus nest on record. These few observations suggest that Pine Snakes in warmer parts of the species' range may typically dig deeper nest chambers and/or nest in more shaded areas than those in the northern portion of the range. This could be an adaptation to the higher summer temperatures in these regions. Nest site fidelity over successive years, and communal nesting, both common behaviors in P. melanoleucus in the New Jersey Pine Barrens (Burger and Zappalorti 1991, 1992), have yet to be documented for the species elsewhere in its range.

Acknowledgments: Fieldwork was made possible by Project Simus, which is supported by the North Carolina Herpetological Society, Wake Audubon Society, Three Lakes Nature Center, the North Carolina State Museum of Natural Sciences, and individual donations. Daniel S. Dombrowski, L. Shane Christian, Gregory A. Lewbart, and students at the North Carolina State University College of Veterinary Medicine assisted with transmitter surgeries. The North Carolina Wildlife Resources Commission provided permits to work with state-listed species on state-owned game lands. 


\section{LITERATURE CITED}

BEANE, J. C., AND L. T. PUSSER. 2007. Pituophis melanoleucus melanoleucus: reproduction. Herpetol. Rev. 38(4):469.

BURGER, J., AND R. T. ZAPPALORTI. 1986. Nest site selection by pine snakes, Pituophis melanoleucus, in the New Jersey Pine Barrens. Copeia 1986(1):116-121.

BURGER, J., AND R. T. ZAPPALORTI. 1991. Nesting behavior of pine snakes (Pituophis m. melanoleucus) in the New Jersey Pine Barrens. J. Herpetol. 25(2):152-160.

BURGER, J., AND R. T. ZAPPALORTI. 1992. Philopatry and nesting phenology of pine snakes (Pituophis melanoleucus) in the New Jersey Pine Barrens. Behav. Ecol. Sociobiol. 30:331-336.
LEE, J. R., D. J. NEWMAN III, AND M. G. HINDERLITER. 2011. Pituophis melanoleucus lodingi: reproduction and nest location. Herpetol. Rev. 42(2):301.

MOORE, J. M. 1893. The eggs of Pituophis melanoleucus. Am. Nat. 27:878-885.

PEARSON, D. J., AND R. SHINE. 2002. Expulsion of intraperitoneally-implanted radiotransmitters by Australian pythons. Herpetol. Rev. 33(4):261-263.

ZAPPALORTI, R. T., E. W. JOHNSON, AND Z. LESZCZYNSKI. 1983. The ecology of the Northern Pine Snake, Pituophis melanoleucus (Daudin) (Reptilia, Serpentes, Colubridae), in southern New Jersey, with special notes on habitat and nesting behavior. Bull. Chicago Herpetol. Soc. 18:57-72. 